\title{
Proces tworzenia Centralnego Rejestru Faktur w Polsce
}

\author{
The process of creating the Central Invoice Register in Poland
}

\section{Wprowadzenie}

Zgodnie z zaleceniami „Zielonej księgi” z 2010 r. w wielu krajach UE powstały Centralne Rejestry Faktur („Zielona księga”, art. 5.4.1.). W Polsce od kilku lat wprowadzane są różne systemy informatyczne służące zwiększeniu nadzoru nad: podatnikami, płatnikami i importerami (Szymanek, 2019, s. 171). W porównaniu jednak z wiodącymi krajami UE systemy te wdrażane są znacznie wolniej. Z dniem 1 października 2020 r. zaczęly obowiązywać przepisy wprowadzające do polskiego systemu prawnego obowiązek wysyłania przez wszystkich podatników plików JPK_VAT, które zastąpiły wcześniej wysyłane pliki JPK oraz deklaracje VAT-7 (Ustawa, 1997, art. 193a; Wyrok NSA, 2020, I FSK 588/20). W artykule przedstawiono historię wprowadzania Centralnego Rejestru Faktur w Polsce. W treści przeanalizowano nieobowiązujący już wymóg składania plików JPK oraz funkcjonujący obowiązek składania plików JPK_VAT. Omówiono wprowadzenie Centralnego Repozytorium Kas. Uwzględniono również planowane wdrożenie systemu KSeF. Ponadto postawiono tezę, zgodnie z którą wprowadzając pliki JKP_VAT z dniem 1 października 2020 r., nie stworzono w Polsce Centralnego Rejestru Faktur, ponieważ JPK_VAT zastąpiły tylko JPK oraz deklaracje VAT-7, nie powodując nowego obowiązku przekazywania wszystkich danych zawartych na fakturach. Na końcu przedstawiono plany Ministerstwa Finansów związane z wdrażaniem Centralnego Rejestru Faktur w Polsce (Projekt, 2021, art. 1). 


\section{Podstawowe modele Centralnego Rejestru Faktur}

Po raz pierwszy pomysł skonstruowania Centralnego Rejestru Faktur (CFR) powstał w 2010 r. w „Zielonej Księdze” celem uszczelnienia systemu podatku od towarów i usług oraz wyeliminowania oszustw podatkowych, a także przyspieszenia i usprawnienia kontroli („Zielona księga”, art. 5.4.1.).

CRF został wprowadzony dla pozyskiwania i gromadzenia w czasie rzeczywistym wszystkich danych z wystawianych w kraju faktur VAT. Stanowi on pełne repozytorium danych fiskalnych (Wyrok WSA w Gorzowie Wlkp., 2019, I SA/Go 516/18). CRF jest bierną kartoteką wszystkich faktur, będącą podstawą do późniejszych ich weryfikacji, stanowiąc bazę danych pozwalających na skuteczne wykrywanie przestępstw podatkowych (Ćwiąkała-Małys i Piotrowska, 2017, s. 85). W systemie tym wszystkie faktury podlegają cyfryzacji i w takiej formie przesyłane są administracji podatkowej do wspólnej bazy danych celem dalszego przetwarzania (Pałys i Daniek, 2018, s. 37).

Generalnie można wyróżnić dwa modele CFR:

- pierwszy, polegający na wystawianiu elektronicznych faktur i przesyłaniu ich do centralnej bazy administracji podatkowej celem dalszego sprawdzania i weryfikowania otrzymanych danych oraz jednoczesnego wysyłania faktur przez podatnika swojemu kontrahentowi (Jendraszczyk, 2019, s. 20);

- drugi, stanowiący rozbudowaną wersję pierwszego modelu, polegający na wystawianiu elektronicznych faktur i przesyłaniu do centralnej bazy administracji podatkowej celem ich autoryzacji, polegającej na sprawdzenia faktur w czasie rzeczywistym pod względem formalnym i materialnym, a także nadania jej cyfrowego kodu, aby podatnik po dokonanej weryfikacji mógł tę fakturę legalnie wprowadzić w obieg, wysyłając ją swojemu kontrahentowi (Ćwiąkała-Małys i Piotrowska, 2018, s. 90).

\section{Pliki JPK poprzedzające pliki JPK_VAT}

Obowiązek wysyłania plików JPK wprowadzono w Polsce ustawą z dnia 10 września 2015 r. o zmianie ustawy - Ordynacja podatkowa oraz niektórych innych ustaw (Ustawa, 2015, art. 1 ust. 130). Na początku jej funkcjonowania podatnicy zobowiązani byli przesyłać pliki JPK wyłącznie na żądanie organu podatkowego (Ustawa, 1997, art. 193a; Oleśniewicz, 2016, s. 21). Obowiązek ich cyklicznego wysyłania został wprowadzony ustawą z 13 maja 2016 r. o zmianie ustawy - Ordynacja podatkowa oraz niektórych innych ustaw (Ustawa, 2016, art. 3 ust. 2). 
W odniesieniu do małych i średnich przedsiębiorstw wprowadziła ona wymóg przekazywania plików JPK od 1 stycznia 2017 r. (Ustawa, 2016, art. 9 ust. 2). Mikroprzedsiębiorcy rozpoczęli ich przesyłanie 1 stycznia $2018 \mathrm{r}$. (Ustawa, 2016, art. 9 ust. 3). Przez ten okres pliki JPK funkcjonowały niezależnie od deklaracji VAT-7, w związku z tym podatnicy mieli obowiązek w tym samym terminie wysłać pliki JPK oraz deklaracje VAT-7 (Wyrok WSA w Warszawie, 2019, III SA/WA 18/19).

Podstawowym celem wprowadzenia plików JPK było: usprawnienie i przyśpieszenie kontroli podatkowych, poprawa wyników kontroli, obniżenie kosztów oraz uszczelnienie systemu podatku od towarów i usług. Strukturę logiczną plików JPK podzielono na 7 części, które dotyczyły w kolejności: ksiąg rachunkowych, wyciągów bankowych, danych z magazynu, ewidencji zakupów i sprzedaży VAT, faktury VAT, podatkowej księgi przychodów i rozchodów, ewidencji przychodów. Informacje zawarte w plikach JPK były zbliżone do danych zawartych w deklaracji VAT-7. Dodatkowo jednak zawierały szczegółowe informacje dotyczące poszczególnych faktur, $\mathrm{w}$ tym ich numery. $\mathrm{W}$ efekcie, po raz pierwszy pojawiła się możliwość bieżącego nadzorowania wielu nowych danych zawartych z wystawianych faktur. Poprzednio otrzymanie tych informacji było możliwe tylko w trybie kontroli lub czynności sprawdzających.

Pojawienie się elektronicznej kontroli nadsyłanych plików JPK, zawierających dane szczegółowe z faktur, należało uznać za właściwą zmianę. Podatnicy wypełniając pliki JPK, wpisywali do nich dane z poszczególnych faktur, podając ich numery, NIP wystawcy, datę wystawienia, kwoty netto i brutto oraz wysokość podatku z nich wynikającego. Jednak analiza danych z plików JPK nie przyczyniła się do ograniczenia wielu nieprawidłowości związanych z funkcjonowaniem podatku od towarów usług, w szczególności karuzel podatkowych, ponieważ przesyłane dane były niepełne. By wyeliminować to oszustwo podatkowe za pomocą analizy plików JPK, należałoby wprowadzić obowiązek przekazywania wszystkich danych z faktury, w tym „przedmiotu sprzedaży”. Dane te nie były jednak wysyłane w plikach JPK, skutkiem czego po przeprowadzeniu analizy ryzyka tylko w przybliżeniu typowano podatników niewypełniających obowiązków podatkowych, bez możliwości precyzyjnego ich wskazania.

\section{Obecne regulacje w Polsce}

Zgodnie z ustawą z dnia 4 lipca 2019 r. o zmianie ustawy o podatku od towarów i usług oraz niektórych innych ustaw (Ustawa z 4.07.2019, art. 1 ust. 23) rozpo- 
częto proces likwidacji deklaracji VAT-7 oraz plików JPK i zastąpienie ich plikami JPK_VAT. W stosunku do dużych podatników wprowadzono obowiązek składania plików JPK_VAT z dniem 1 kwietnia 2020 r., dla małych podatników obowiązek ten powstał z dniem 1 października 2020 r. (Ustawa z 4.07.2019, art. 28 ust. 6).

Plik JPK_VAT składa się z dwóch części: pierwsza zawiera wyciąg z ewidencji podatku od towarów i usług dotyczący informacji o zakupach i sprzedaży, druga - dane wynikające z dotychczasowej deklaracji VAT-7 (Rozporządzenie Ministra Finansów, Inwestycji i Rozwoju, 2019, par. 4 i 10; Jendraszczyk, 2019, s. 20). Pliki JPK_VAT składane są obowiązkowo przez wszystkich zarejestrowanych i czynnych podatników w okresach miesięcznych lub kwartalnych. Ich treść uregulowana została w rozporządzeniu Ministra Finansów, Inwestycji i Rozwoju z dnia 15 października 2019 r. w sprawie szczegółowego zakresu danych zawartych w deklaracjach podatkowych i w ewidencji w zakresie podatku od towarów i usług (Rozporządzenie Ministra Finansów, Inwestycji i Rozwoju, 2019, par. 2).

Pierwsza część plików JPK_VAT stanowi powtórzenie pozycji z deklaracji VAT-7 i VAT-7K (Rozporządzenie Ministra Finansów, Inwestycji i Rozwoju, 2019, par. 2). Informacjami tymi są:

1. oznaczenie właściwego urzędu skarbowego,

2. dane identyfikacyjne podatnika,

3. oznaczenie czy jest to rozliczenie miesięczne lub kwartalne,

4. oznaczenie okresu, za który podatek jest rozliczany,

5. oznaczenie wersji (kodu) deklaracji,

6. data sporządzenia,

7. wskazanie czy deklaracja jest składana po raz pierwszy czy jest korektą,

8. dane niezbędne do obliczenia wysokości: podatku należnego, podatku naliczonego, podatku lub zwrotu podatku wraz z oznaczeniem sposobu dokonania tego zwrotu, dodatkowe dane dotyczące rozliczenia.

Druga część plików JPK_VAT, związana z ewidencją VAT, w przeważającej części pokrywa się z danymi dotychczas wysyłanymi w plikach JPK (Rozporządzenie Ministra Finansów, Inwestycji i Rozwoju, 2019, par. 9), zawierając:

1. dane identyfikacyjne podatnika,

2. oznaczenie okresu, którego dotyczy ewidencja (miesiąc/kwartał i rok),

3. dane pozwalające na prawidłowe rozliczenie podatku należnego,

4. dane pozwalające na prawidłowe rozliczenie podatku naliczonego.

W porównaniu ze zlikwidowanymi plikami JPK oraz deklaracjami VAT-7 nowe pliki JPK_VAT zawierają informacje dotyczące dostaw niektórych towarów i usług mających szczególne znaczenie dla budżetu państwa. Podatnik w przypadku dokonywania sprzedaży ściśle określonych towarów i usług ma obowiązek podać 
specjalny kod GTU. Informacja ta jest przesyłana w pliku JPK_VAT organom KAS. W szczególności podatnik zobowiązany jest ten sposób oznaczyć:

- sprzedaż alkoholu - kod GTU 1,

- handel paliwem - kod GTU 2,

- sprzedaż oleju opałowego i olejów smarowych - kod GTU 3,

- wyroby tytoniowe - kod GTU 4,

- handel odpadami, surowcami wtórnymi itp. - kod GTU 5,

- urządzenia elektroniczne - kod GTU 6,

- sprzedaż pojazdów i części - kod GTU 7,

- wyroby z metali szlachetnych i nieszlachetnych, jubilerskie - kod GTU 8,

- handel lekami - kod GTU 9,

- budynki i budowle - kod GTU 10,

- usługi w zakresie przenoszenia uprawnień do emisji gazów cieplarnianych - kod GTU 11,

- usługi o charakterze niematerialnym, m.in. doradcze, księgowe, prawne, zarządcze, szkoleniowe, marketingowe, firm centralnych (head offices), reklamowe, badania rynku i opinii publicznej, w zakresie badań naukowych i prac rozwojowych - kod GTU 12,

- usługi transportowe i gospodarki magazynowej - kod GTU 13 (Rozporządzenie Ministra Finansów, Inwestycji i Rozwoju, 2019, par. 3 i 4).

Obowiązek podawania informacji o sprzedaży wymienionych towarów i usług poprzez podanie kodu w GTU jest kolejnym uszczegółowieniem przekazywanych informacji organom KAS w formie plików JPK_VAT w przeciwieństwie do ich poprzedników. W ten sposób organy KAS mogą na bieżąco monitorować sprzedaż wymienionych towarów i usług, których dobór nie jest przypadkowy. Obrót takimi towarami jak: alkohol, paliwa, papierosy, olej opałowy stanowi główny wpływ do budżetu państwa ze względu na ich opodatkowanie podatkami: od towarów i usług oraz podatkiem akcyzowym. Z kolei handel urządzeniami elektronicznymi, odpadami, pojazdami i ich częściami oraz wyrobami z metali szlachetnych stanowił przedmiot sprzedaży w karuzelach podatkowych, ponieważ towary te generowały wysokie obroty służące wysokim zwrotom nadpłaty podatku naliczonego nad podatkiem należnym. $Z$ tych samych powodów na liście umieszczono obowiązek podawania kodu GTU przy sprzedaży uprawnień do emisji gazów cieplarnianych. W trakcie obrotu tymi uprawnieniami dochodziło do ogromnych nadużyć, które były związane z odmiennym sposobem naliczania podatku VAT na poziomie krajowym i w obrocie na terenie UE. Skutkiem powyższego dochodziło do nieprawidłowych zwrotów nadwyżki podatku naliczonego nad podatkiem należnym. Analogicznie postąpiono w przypadku handlu lekami, które 
wykorzystywane były do fikcyjnego eksportu celem uzyskania zwrotu nadwyżki podatku naliczonego nad należnym. Niezbędnym elementem funkcjonowania karuzel podatkowych były również faktury transportowe oraz magazynowe, które rzekomo potwierdzać miały dokonywanie obrotu wymienionymi towarami. Z tego też powodu usługi te zostały objęte obowiązkiem informacyjnym celem wyeliminowania możliwości tworzenia karuzel podatkowych. Powodem zamieszczenia na liście sprzedaży budynków oraz nieruchomości było generowanie olbrzymich obrotów z tego tytułu, natomiast wpisanie pozostałych usług niematerialnych spowodowane zostało nadużyciami przy wystawianiu faktur kosztowych zmniejszających podatki dochodowe i podatek od towarów i usług za niewykonane w rzeczywistości usługi.

Dzięki wprowadzeniu obowiązku oznaczania symbolami GTU wymienionych towarów i usług organy KAS otrzymują na bieżąco informacje o tych transakcjach. Minusem obecnych regulacji jest ograniczenie przekazywanych danych do 13 grup towarów i usług, wynikiem czego nadzorowana przez organy KAS jest tylko część obrotu w skali kraju. Problem ten zostałby rozwiązany, gdyby w formie plików JPK_VAT przekazywano wszystkie informacje zawierane na fakturach, w tym „przedmiot sprzedaży”. Wówczas organy KAS otrzymywałyby pełną informację o wszystkich transakcjach, a nie tylko o sprzedaży towarów i usług objętych obowiązkiem oznaczania kodami GTU. Obecne regulacje nie pozwalają na precyzyjne ustalanie powiązań pomiędzy podatnikami celem wyeliminowania wszystkich oszustw podatkowych.

Drugim negatywnym skutkiem wprowadzonych regulacji jest skomplikowany charakter tych przepisów, powodujący liczne problemy związane z prawidłowym ich stosowaniem. Na stronie internetowej Ministerstwa Finansów „podatki. gov.pl" przedstawione są liczne wyjaśnienia, jak stosować te przepisy. Objaśnienia te oczywiście nie mają charakteru wiążącego, jednak powszechnie wiadome jest, że wszystkie organy KAS w trakcie ewentualnych czynności sprawdzających oraz kontroli stosować się będą do zamieszczonych wyjaśnień. Obecnie znajduje się tam ich ponad 40, z których można dowiedzieć się m.in., że podatnik nie ma obowiązku dodatkowego oznaczenia symbolami GTU faktur, ponieważ dotyczy on tylko i wyłącznie przekazywanych informacji w formie plików JPK_VAT, ma jednak obowiązek oznaczać wszystkimi symbolami GTU sprzedaż, jeżeli na jednej fakturze znajduje się kilka towarów podlegających temu obowiązkowi (Ministerstwo Finansów, 2021, nr 1 i 2). Ponadto podatnik ma obowiązek oznaczać symbolami GTU sprzedaż dokonywaną za pośrednictwem faktur zaliczkowych lub sprzedaż towarów używanych, a także refakturowanie usług wymienionych w kodach GTU (Ministerstwo Finansów, 2021, nr 5, 7 i 11). Ze względu na to, 
że olej opałowy jest wymieniony w dwóch grupach towarów, w przypadku jego sprzedaży podatnik zobowiązany jest do jednoczesnego stosowania oznaczeń: GTU 02 i GTU 03 (Ministerstwo Finansów, 2021, nr 14). Ponadto dla obowiązku oznaczania kodami GTU nie ma znaczenia sposób zużycia tego oleju przez nabywcę, ponieważ jego sprzedaż każdorazowo podlega obowiązkowi oznaczania symbolami GTU (Ministerstwo Finansów, 2021, nr 17). Z kolei usługi budowlane nie podlegają oznaczaniu symbolami GTU, ponieważ obowiązek ten nałożony jest tylko na dostawy: budynków, budowli i gruntów, nawet jeżeli dostawa dotyczy tylko ich części (Ministerstwo Finansów, 2021, nr 20 i 22).

Konstatując, pomimo zwiększania ilości przekazywanych danych do organów KAS w formie plików JPK_VAT, z dniem 1 października 2020 r. nie wprowadzono w Polsce Centralnego Rejestru Faktur, ponieważ plikami JPK_VAT zastąpiono tylko dotychczas otrzymywane informacje z plików JPK oraz deklaracji VAT-7 (Rozporządzenie Ministra Finansów, Inwestycji i Rozwoju, 2019, par. 2 i 9), jednocześnie nie wprowadzając obowiązku przekazywania wszystkich danych z faktur organom KAS.

\section{Plany stworzenia Centralnego Rejestru Faktur w Polsce}

Zgodnie z planami CRF ma powstać dopiero w $2021 \mathrm{r}$. Z dniem 1 lutego $2021 \mathrm{r}$. Ministerstwo Finansów przygotowało projekt zmiany ustawy z dnia 11 marca 2004 r. o podatku od towarów i usług, zgodnie z którym z dniem 1 października 2021 r. planowane jest wprowadzenie Krajowego Systemu e-Faktur (KSeF) (Projekt, 2021, art. 9). Projektowana ustawa przewiduje wprowadzenie faktur elektronicznych, zwanych fakturami ustrukturyzowanymi (Projekt, 2021, art. 1 ust. 1). Będą one funkcjonowały w obrocie gospodarczym niezależnie od dotychczasowych faktur papierowych oraz elektronicznych. Faktury ustrukturyzowane będą wystawiane i otrzymywane przez podatników za pośrednictwem KSeF (Projekt, 2021, art. 1 ust. 8). Zgodnie z projektem w nowym artykule 106nc ustawy o podatku od towarów i usług uregulowano wszystkie funkcje oraz cele, jakie mają być osiągnięte za pośrednictwem KSeF (Projekt, 2021, art. 1 ust. 8). Zgodnie z projektowanym przepisem KSeF będzie systemem służącym do uwierzytelniania oraz weryfikacji posiadanych przez podatnika ustrukturyzowanych faktur, powiadamiania podatnika o posiadanych uprawnieniach do wystawiania i dostępu do faktur ustrukturyzowanych, otrzymywania faktur ustrukturyzowanych, przechowywania ich w systemie przez 10 lat, nadawania 
im numerów identyfikacyjnych oraz weryfikowania zgodności wystawionej faktury ustrukturyzowanej ze wzorem. Co najważniejsze, system ten nie będzie tylko miejscem wystawiania, przesyłania i przechowywania faktur zgodnych z ustalonym wzorem, lecz będzie także służył do analizy i kontroli prawidłowości danych z faktur ustrukturyzowanych (Projekt, 2021, art. 1 ust. 8). Przepis spotkał się z dużym sprzeciwem Związku Przedsiębiorców i Pracodawców, którzy postulowali wprowadzenie zmian umożliwiających dokonywanie kontroli i analizy faktur znajdujących się w KSeF dopiero po wszczęciu postępowania kontrolnego stosownym postanowieniem (Związek Przedsiębiorców i Pracodawców, 2021, s. 2). Uwzględnienie jednak tego postulatu wydaje się niemożliwe, ponieważ proponowana zmiana zaprzecza celom, jakie stawiane są przed CRF we wszystkich krajach. CRF ma służyć do automatycznego, informatycznego przetwarzania danych celem wyeliminowania funkcjonujących nieprawidłowości w podatku od towarów i usług. Pracodawcy Rzeczypospolitej Polskiej zwrócili również uwagę na fakt braku potrzeby przekazywania w trakcie zwykłej kontroli faktur, które zostały wystawione za pośrednictwem systemu KSeF, uznając, że sam fakt przechowywania tych faktur umożliwia każdorazowy do nich dostęp przez wszystkie organy KAS (Pracodawcy Rzeczypospolitej Polskiej, 2021, s. 15). Wydaje się, że ta uwaga również zostanie pominięta, ponieważ dostęp do danych znajdujących się w KSeF będzie ograniczony dla wąskiej grupy pracowników i w trakcie zwykłej kontroli podatnik ponownie będzie zobowiązany do przedstawienia wszystkich faktur, również tych znajdujących się bazie KSeF.

Zgodnie z projektowanymi przepisami podatnicy będą mogli przesyłać kontrahentowi wystawiane przez siebie ustandaryzowane faktury poprzez platformę e-Urząd Skarbowy. Początkowo podatnicy mają dokonywać tych czynności dobrowolnie (Projekt, 2021, art. 1 ust. 8). Zgodnie z dalszymi planami przedsiębiorcy osiągający duże obroty miesięczne będą zobligowani do przesyłania faktur ustandaryzowanych. Ostatecznie obowiązek ten ma objąć swym zasięgiem wszystkich podatników. Plan wprowadzenia powszechnego CRF jest więc odległy i dopiero za kilka lat powstanie taka baza danych w kształcie, jaki funkcjonuje w innych krajach (Ćwiąkała-Małys i Piotrowska, 2018, s. 97; „Zielona księga”, art. 5.4.1.).

Dzięki opisywanej reformie w przyszłości, po stworzeniu KSeF, KAS otrzyma dostęp do faktur w czasie rzeczywistym, a podatnicy uzyskają w obrocie faktury wolne od błędów formalnych, poprawne rachunkowo oraz zaakceptowane przez właściwe organy, przez co zyskają pewność obrotu gospodarczego. Faktury będą parowane pomiędzy sprzedawcami i kupującymi, eliminując patologię polegającą na wykazywaniu wyłącznie faktur zakupowych (podlegających odliczeniu) bez jednoczesnego wykazywania faktur do opodatkowania przez kontrahenta, co 
było nagminnym problemem funkcjonowania w obrocie faktur papierowych. Uproszczony zostanie system czynności sprawdzających oraz kontrolnych, co skutkować będzie zmniejszeniem liczby tych kontroli oraz większą ich skutecznością. Na bieżąco sprzedawca będzie mógł w czasie rzeczywistym sprawdzić, czy jego kontrahent pobrał fakturę.

Dodatkowo w planach przewidziana jest opcja płacenia faktur online za pośrednictwem serwera KAS. Będzie to jednak związane z dodatkowym uruchomieniem szeregu systemów integrujących e-Urząd Skarbowy z e-płatnościami.

\section{Centralne Repozytorium Kas}

Niezależnie od tworzenia CRF dla wystawianych faktur stworzono Centralne Repozytorium Kas (CRK) dla wystawianych paragonów fiskalnych (Ustawa, 2004, art. 11la). Zasadnicze cele CRF są jednak zupełnie inne niż CRK. CRF służy rejestracji faktur oraz analizie otrzymanych informacji celem wyeliminowania nieprawidłowych mechanizmów funkcjonowania podatku od towarów i usług, w tym wyeliminowania karuzel podatkowych. Stworzenie CRK ma natomiast na celu spowodowanie rejestrowania pełnego obrotu za pośrednictwem kas. CRK nie będzie więc służyło do wyeliminowania karuzel podatkowych, ponieważ kasy rejestrujące nie są wykorzystywane przy tego rodzaju przestępstwach.

Przed stworzeniem CRK wykorzystywane były w Polsce wyłącznie tradycyjne kasy fiskalne rejestrujące obroty w pamięci fiskalnej lub w formie papierowej. Niestety funkcjonowanie tych kas związane było z nieewidencjonowaniem pełnego obrotu przy ich użyciu, pomimo istnienia takiego obowiązku. Celem wyeliminowania tego procederu wprowadzono obowiązek używania kas online oraz kas wirtualnych.

Pod pojęciem kasy online rozumie się kasę rejestrującą w formie fizycznego urząazenia, komunikującą się na bieżąco z CRF i przesyłającą online dane o wystawionych paragonach. Z dniem 1 stycznia 2020 r. kasy online stały się obowiązkowe w działalnościach związanych $\mathrm{z}$ naprawą pojazdów oraz sprzedażą paliw silnikowych (Ustawa z 15.03.2019, art. 1 ust. 7). Następnie obowiązek ten objął branżę gastronomiczną oraz sprzedaży: węgla, brykietu oraz paliw stałych (Rozporządzenie Ministra Finansów z 10.06.2020, par. 1 ust. 1). Z dniem 1 lipca 2021 r. planowane jest wprowadzenie tego obowiązku dla usług: fryzjerskich, kosmetycznych, budowlanych, medycznych, prawniczych i związanych z poprawą kondycji fizycznej (Rozporządzenie Ministra Finansów z 10.06.2020, par. 1 ust. 2).

Pod pojęciem kasy wirtualnej rozumie się kasę rejestrującą w formie oprogramowania do instalacji na tablecie, smartfonie lub komputerze. $\mathrm{Z}$ dniem 
1 czerwca 2020 r. kasy wirtualne rozpoczęly funkcjonowanie w branży: transportowej, hotelarskiej oraz gastronomicznej (Rozporządzenie Ministra Finansów z 29.05.2020, par. 3).

Wymienione branże obejmowane obowiązkiem stosowania kas wirtualnych oraz online nie zostały wybrane przypadkowo. Sprzedaż usług związanych z naprawą pojazdów, gastronomicznych, fryzjerskich, kosmetycznych, budowlanych, medycznych, prawniczych, a także sprzedaż węgla i brykietów charakteryzuje pewna specyfika. Jeżeli sprzedaż ta dokonywana jest za pośrednictwem dużych podmiotów posiadających sieć lokali na terenie całego kraju, wówczas obrót w takich podmiotach rejestrowany jest za pomocą kas rejestrujących z pamięcią elektroniczną lub papierową, ponieważ właściciel wszystkich lokali bardzo często działających $\mathrm{w}$ formie franczyzy chce mieć rejestrowany obrót, gdyż tylko w takiej formie ma nad nim kontrolę. Jednak znaczna część tych usług świadczona jest przez małe podmioty posiadające pojedyncze punkty sprzedaży. W takich podmiotach bardzo często dochodzi do nierejestrowania obrotu za pośrednictwem dotychczasowych kas. To właśnie ze względu na nierejestrowanie obrotu u mikroprzedsiębiorców branże te obejmowane są obowiązkiem rejestrowania obrotu za pomocą kas online oraz wirtualnych.

Wprowadzenie do obrotu nowych kas fiskalnych, w szczególności kas wirtualnych, spotkało się z krytyczną oceną organizacji branżowych. Podkreślano, że korzystanie z kas online, a w szczególności z kas wirtualnych, związane jest z posiadaniem stałego łącza internetowego (Organizacja Pracodawców Branży Fiskalnej, 2020, s. 4). Niestety podatnicy nie mają wpływu na jego jakość, skutkiem czego ci uczciwi nie zawsze będą mogli wystawiać paragony, ponieważ nie zawsze będą korzystać z tego połączenia, a nieuczciwi będą powoływać się na jego brak celem nieewidencjonowania obrotu, który w rzeczywistości jest. Ponadto podkreślano, że z chwilą wejścia w życie kas wirtualnych organy KAS nie uzyskują żadnego nowego narzędzia kontrolnego, a nowe obowiązki po stronie podatników generują dodatkowe trudności z ich wdrożeniem (KIGEiT, 2020, s. 4). Postulowano, że obowiązkowe korzystanie z kas online, a w szczególności z wirtualnych kas, spowoduje zmniejszenie wpływów budżetowych, a nie ich zwiększenie. Ponadto wskazywano na wysokie koszty związane z wdrażaniem tych obowiązków. Jednak po kilku miesiącach funkcjonowania nowych kas brak jest wyraźnych sygnałów, aby podatnicy powoływali się na brak połączenia $\mathrm{z}$ internetem $\mathrm{w}$ trakcie korzystania z kas wirtualnych. Jednocześnie wysoka cena urządzeń nie spowodowała nierespektowania obowiązku zainstalowania kas online oraz wirtualnych.

Rzeczywisty problem nowych kas jest nieco inny niż wymieniany w postulatach branżowych. Nowe kasy przesyłają dane o wystawionych paragonach 
online do CRK, co miało zapewnić regularne ewidencjonowanie obrotu za ich pośrednictwem. Zmiana ta jednak była pozorna, ponieważ nieewidencjonowanie obrotu za pomocą kasy rejestrującej dotyczy każdego przypadku. Nie ma znaczenia, czy kasa gromadzi dane papierowe, elektroniczne, online lub w formie wirtualnej. Jeżeli obrót nie jest ewidencjonowany za pomocą kasy, również nie będzie prowadzony za pomocą nowych kas. Skoro nałożenie obowiązku ewidencjonowania sprzedaży za pomocą kas tradycyjnych nie wymusiło na podatnikach obowiązku wprowadzania do nich wszystkich danych, nowe kasy online oraz wirtualne nie spowodują żadnych zmian w tym aspekcie.

Jednocześnie wprowadzenie kas online oraz wirtualnych przynosi dodatkowe korzyści. Po pierwsze, podatnicy nie gromadzą danych w papierowej formie, co ma znaczenie dla tych, którzy posiadają wiele kas fiskalnych, jak np. właściciele sieci sklepów. Po drugie, dane napływające automatycznie do CRK w przeciwieństwie do papierowej formy mogą być na bieżąco analizowane celem wykorzystania do ewentualnych kontroli.

\section{Zakończenie}

CRF służy pozyskiwaniu i gromadzeniu w czasie rzeczywistym wystawianych w kraju faktur VAT, będąc repozytorium wszystkich danych fiskalnych, pozwalając na skuteczne wykrywanie przestępstw podatkowych (Ćwiąkała-Małys i Piotrowska, 2018, s. 90). W UE po raz pierwszy pomysł wprowadzenia CRF powstał w 2010 r. w „Zielonej Księdze” („Zielona księga”, art. 5.4.1.). W Polsce w celu jego stworzenia dokonywano licznych zmian przepisów, wprowadzając obowiązek wysyłania plików JPK, a następnie JPK_VAT. Sukcesywnie zwiększano zakres informacyjny poprzez przekazywanie kolejnych nowych informacji organom KAS, co regularnie zwiększało skuteczność raportów. Mimo to do dnia dzisiejszego nie stworzono CRF w Polsce, ponieważ z dniem 1 kwietnia 2020 r. nie wprowadzono obowiązku przesyłania wszystkich danych wynikających z faktur, lecz wyłącznie zastąpiono nowymi plikami dotychczasowe dane wynikające z plików JPK oraz deklaracji VAT-7, co potwierdza w całości postawioną na wstępie tezę. Z dniem tym nie stworzono CRF, lecz zreorganizowano sposób otrzymywania tych samych informacji w bardziej przystępny dla podatników sposób. W CRF powinny być gromadzone wszystkie dane, w tym dotyczące przedmiotu sprzedaży. Obecnie przekazywane informacje w formie plików JPK_VAT, pomimo dodawania kodów GTU, nie zwierają wyżej wymienionych danych, ponieważ kody te odnoszą się tylko do 13 branż. Skutkiem tego informacje wynikające 
z plików JPK_VAT uniemożliwiają precyzyjne wyeliminowanie wszystkich oszustw podatkowych oraz powiązania gospodarcze podatników, typując tylko w przybliżeniu podmioty do kontroli.

Zgodnie z planami dopiero za kilka lat powstanie taka baza danych. Niestety wprowadzany 1 października $2021 \mathrm{r}$. KSeF przewiduje tylko dobrowolną możliwość wystawiania faktur ustrukturyzowanych. Z założenia więc tworzona ich baza w KSeF nie będzie zawierała wszystkich faktur funkcjonujących w obrocie gospodarczym. CRF powstanie w Polsce dopiero z chwią nałożenia obowiązku wysyłania wszystkich danych wynikających z faktur VAT organom KAS.

\section{Bibliografia}

\section{Akty prawne}

Ustawa z 29.08.1997 - Ordynacja podatkowa, tekst jedn. Dz.U. 2019, poz. 900 z późn. zm. Ustawa z 11.03.2004 o podatku od towarów i usług, Dz.U. 2004, nr 54, poz. 535 z późn. zm. Ustawa z 10.09.2015 o zmianie ustawy - Ordynacja podatkowa oraz niektórych innych ustaw, Dz.U. 2015, poz. 1649.

Ustawa z 13.05.2016 o zmianie ustawy - Ordynacja podatkowa oraz niektórych innych ustaw, Dz.U. 2016, poz. 846 z późn. zm.

Ustawa z 15.03.2019 o zmianie ustawy o podatku od towarów i usług oraz ustawy - Prawo o miarach, Dz.U. 2019, poz. 675.

Ustawa z 4.07.2019 o zmianie ustawy o podatku od towarów i usług oraz niektórych innych ustaw, Dz.U.2019, poz. 1520 z późn. zm.

„Zielona księga” w sprawie przyszłości podatku VAT - W stronę prostszego, solidniejszego i wydajniejszego podatku VAT, Bruksela, dnia 1.12.2010r. KOM (2010) 695 wersja ostateczna.

Projekt z dnia 1 lutego 2021 r. ustawy o zmianie ustawy o podatku od towarów i usług oraz niektórych innych ustaw, https://legislacja.rcl.gov.pl/docs//2/12343202/12 762050/12762051/

dokument487851.pdf (17.03.2021).

Rozporządzenie Ministra Finansów, Inwestycji i Rozwoju z dnia 15 października 2019 r. w sprawie szczegółowego zakresu danych zawartych w deklaracjach podatkowych i w ewidencji w zakresie podatku od towarów i usług (Dz.U poz. 1988).

Rozporządzenie Ministra Finansów z dnia 26 maja 2020 r. w sprawie kas rejestrujących mających postać oprogramowania (Dz.U. 2020 poz. 957).

Rozporządzenie Ministra Cyfryzacji z dnia 28 maja 2020 r. w sprawie aplikacji mobilnej służącej do rozliczania opłaty za przewóz osób, Dz.U. 2020, poz. 954. 
Rozporządzenie Ministra Finansów z dnia 29 maja 2020 r. w sprawie grup podatników lub rodzajów czynności, w odniesieniu do których możliwe jest używanie kas rejestrujących mających postać oprogramowania, Dz.U. 2020, poz. 965.

Rozporządzenie Ministra Finansów z dnia 10 czerwca 2020 r. w sprawie przedłużenia terminów prowadzenia ewidencji sprzedaży przy zastosowaniu kas rejestrujących z elektronicznym lub papierowym zapisem kopii, Dz.U. 2020, poz. 1059.

\section{Orzecznictwo}

Wyrok NSA z 16.06.2020, I FSK 588/20.

Wyrok WSA w Gliwicach z 31.07.2020 r., I SA/Gl 283/20.

Wyrok WSA w Gorzowie Wlkp. z 20.02.2019, I SA/Go 516/18.

Wyrok WSA w Lublinie z 15.07.2019, I SA/Lu 756/19.

Wyrok WSA w Łodzi z 10.06.2020, I SAB/Łd 12/20.

\section{Literatura}

Adamczyk-Kaczmara, S. (2019). Zmiany w zakresie kas rejestrujących jako przejaw działań zmierzających do uszczelniania systemu podatkowego. Krytyka Prawa, 2, 12-26.

Bielecki, L., Gorgol, A. (red.). (2018). Ustawa o Krajowej Administracji Skarbowej. Komentarz, Warszawa: C.H. Beck.

Bitner, M., Chojna-Duch, E., Chowaniec, J., Grzybowski, M., Karwat, P., Kornberger-Sokołowska, E., ... Waluga M. (2017). Prawo finansowe: prawo finansów publicznych, prawo podatkowe, prawo bankowe. Warszawa: Wolter Kluwer.

Brzeziński, B., Lasiński-Sulecki, K., Morawski, W. (red.). (2018a). Nowe narzędzia kontrolne, dokumentacyjne i informatyczne $w$ prawie podatkowym. Poprawa efektywności systemu podatkowego. Warszawa: Wolters Kluwer.

Brzeziński, B., Lasiński-Sulecki, K., Morawski, W. (red.). (2018b), Nowe narzędzia prawne w podatkach dochodowych i majątkowych. Poprawa efektywności systemu podatkowego. Warszawa: Wolters Kluwer.

Brzeziński, B., Lasiński-Sulecki, K., Morawski, W. (red.). (2018c). Poprawa efektywności systemu podatkowego. Nowe narzędzia prawne w VAT i akcyzie. Warszawa: Wolters Kluwer.

Brzeziński, B., Kalinowski, M., Olesińska, A. (2017). Ordynacja podatkowa. Komentarz praktyczny. Gdańsk: ODDK.

Ćwiąkała-Małys, A., Piotrowska, I. (2017). Jednolity plik kontrolny i centralny rejestr faktur jako elektroniczne narzędzia wspierające skuteczność administracji skarbowej. Przedsiębiorczość i Zarzadzanie, 18(7/2), 81-100.

Ćwiąkała-Małys, A., Piotrowska, I. (2018). Centralny rejestr faktur i zmiany w przepisach karnych i karnych skarbowych jako sposoby ograniczania zjawiska 
pustych faktur. Prace Naukowe Uniwersytetu Ekonomicznego we Wrocławiu, $513,88-98$.

Drewniak, Z., Majewski, P., Płókarz, R., Tokarski, A. (red.). (2016). Dylematy i perspektywy rozwoju rachunkowości i podatków. Toruń: Wyższa Szkoła Bankowa.

Etel, L. (red.). (2017). Ordynacja podatkowa. Komentarz. Warszawa: Wolters Kluwer.

Fornalik, J., Ziętek, J. (2019). Rewolucja technologiczna w podatkach. Krytyka Prawa, $11(2), 62-74$.

Gajewski, D. (red.). (2020). Uszczelnienie systemu podatkowego w Polsce. Warszawa: Wolters Kluwer.

Góralska, J. (2017). Wdrożenie jednolitego pliku kontrolnego w praktyce działalności gospodarczej małych i średnich przedsiębiorstw. Finanse, Rynki Finansowe, Ubezpieczenia, 4(88), 263-271.

Grzanka, P., Sidelnik, M. (red.). (2018). Jednolity Plik Kontrolny. Obowiązki e-raportowania danych podatkowych w 2018 roku. Warszawa: Wolters Kluwer.

Jabłoński, A., Kuczyńska, M., Pietrzak, Z., Wnuk-Pel, T. (2016). Oczekiwany wpływ implementacji zintegrowanego systemu informatycznego na jakość informacji - studium przypadku. Zeszyty Teoretyczne Rachunkowości, 89(145), 55-75.

Jendraszczyk, M. (2020). Likwidacja VAT-7 i VAT-7K oraz wprowadzenie nowej rozbudowanej wersji JPK_VAT - skutki dla podatników. Biuletyn Instytutu Studiów Podatkowych, 2(282), 19-22.

KIGEiT. (2002). Pobrano z https://kigeit.org.pl (23.03.2021).

Krawczak, M., Zalewski, D. (red.). (2019). Kontrola podatkowa działalności gospodarczej. Warszawa: Wolters Kluwer.

Kruba, P., Masiukiewicz, A. (2020). Platforma dystrybucji eParagonów. Stan aktualny i wdrożenia. Kwartalnik Nauk o Przedsiębiorstwie, 2, 83-93.

Melezini, A., Teszner, K. (red.). (2018). Krajowa Administracja Skarbowa. Komentarz. Warszawa: Wolters Kluwer.

Mielniczuk-Stelmach, M. (2018). Metody przeciwdziałania wyłudzeniom w podatku od towarów i usług spowodowanym działaniem karuzeli VAT-owskich. Prace Naukowe Uniwersytetu Ekonomicznego we Wrocławiu, 528, 153-163.

Ministerstwo Finansów. (b.d.). Pytania i odpowiedzi, Wypełnianie JPK_VAT z deklaracja. Pobrane z https://www.podatki.gov.pl/jednolity-plik-kontrolny/jpk-vat-z-deklaracja/faq-jpk-vat-z-deklaracja/\#gtu (18.04.2021).

Modzelewski, W. (2019a). Komentarz do ustawy o podatku dochodowym od osób prawnych. Warszawa: Instytut Studiów Podatkowych.

Modzelewski, W. (2019b). Myśli chore 2019-2020. Warszawa: Instytut Studiów Podatkowych. 
Oleśniewicz, J. (2016). JPK - wstęp do cyfryzacji rachunkowości i rewizji finansowej. Rachunkowość, 8, 17-22.

Organizacja Pracodawców Branży Fiskalnej. (2020). Pobrano z https://opbf.org.pl/wp-content/uploads/2020/05/OPBF_grupy_softwarowe-9.pdf (23.03.2021).

Pałys, A., Daniek, Ł. (2018). Krok milowy w stronę elektronicznych rozliczeń podatkowych. Czy ewidencja JPK_VAT może zastąpić deklarację VAT?. Przegląd Podatkowy, 11, 35-40.

Pracodawcy Rzeczypospolitej Polskiej. (2021). Stanowisko Pracodawców Rzeczypospolitej Polskiej wobec projektu $z$ dnia 1 lutego 2021 o zmianie ustawy o podatku od towarów i usług oraz niektórych innych ustaw. Pobrano z https://legislacja.rcl. gov.pl/docs//2/12343202/12762044/12762047/dokument495213.pdf(24.03.2021).

Różycki, K. (2018). Kontrola celno-skarbowa. Komentarz. Wzory, zestawienia i procedury kontrolne. Warszawa: Wolters Kluwer.

Rudowski, J., Ożóg, I. (red.). (2020). Karuzele i inne oszustwa podatkowe. Metody przeciwdziałania unikaniu opodatkowania. Warszawa: Wolters Kluwer.

Sarnowski, J., Selera, P. (2021). Narzędzia informatyczne w administracji skarbowej i ich wpływ na szczelność systemu podatkowego w Polsce w latach 2015-2019. Studia BAS, 4, 29-50.

Schneider, K., Schneider, K. (2018). Zagrożenia w funkcjonowaniu jednolitego pliku kontrolnego. Ekonomiczne Problemy Usług, 2(131), 323-330.

Stanik, K., Winiarski, K. (2013). Praktyczne problemy nadużycia i obejścia prawa podatkowego. Wrocław: Oficyna Wydawnicza UNIMEX.

Szymanek, P. (2019). Ewolucja ustroju i kompetencji rządowych organów podatkowych, celnych oraz kontroli skarbowej - sprawujących nadzór nad podatnikami, płatnikami i importerami (lata 1991-2017). Warszawa: Kancelaria Prawna i Podatkowa.

Voss, G. (2016). Uproszczenia w sprawozdawczości finansowej w mikro i małych przedsiębiorstwach. Zeszyty Naukowe Uniwersytetu Szczecińskiego, Finanse, Rynki Finansowe, Ubezpieczenia, 5, 151-161.

Voss, G. (2017). Jednolity Plik Kontrolny - koszty i korzyści cyfryzacji. Finanse, Rynki Finansowe, Ubezpieczenia, 4(88), 185-195.

Związek Przedsiębiorców i Pracodawców. (2021). Stanowisko ZPP ws. e-faktur. Pobrano z https://legislacja.rcl.gov.pl/docs//2/12343202/12762044/12762047/dokument495220.pdf (dostęp: 24.03.2021).

\section{Streszczenie}

W artykule przedstawiono historię wprowadzania Centralnego Rejestru Faktur w Polsce. W treści przeanalizowano nieobowiązujące pliki JPK oraz funkcjonujące pliki JPK_VAT. Omówiono wprowadzenie Centralnego Repozytorium Kas. Uwzględniono również 
planowane wprowadzenie systemu KSeF. Wbrew licznym publikacjom prasowym postawiono tezę, że z dniem 1 października 2020 r. nie stworzono w Polsce Centralnego Rejestru Faktur, ponieważ stosowany od tego dnia system JPK_VAT wyłącznie zastąpił pliki JPK oraz deklaracje VAT-7, nie wprowadzając nowego obowiązku przekazywania wszystkich danych zawartych w fakturach. Końcowo przedstawiono plany Ministerstwa Finansów związane z ostatecznym wdrożeniem Centralnego Rejestru Faktur w Polsce.

SŁowA KLUCzowe: Centralny Rejestr Faktur, Zielona księga, podatek od towarów i usług, JPK, JPK-VAT.

\section{Summary}

The article presents the history of introducing the Central Registers of Invoices in Poland, on the examples of: Portugal, Spain, Hungary, Italy and Great Britain, as well as Brazil - the leading country from outside the EU, which already in 2002 began the digitization of the process of settling public liabilities for taxpayers. The content analyzes the no longer binding obligation to submit JPK files and the existing obligation to submit JPK_VAT files. The introduction of the Central Repository of Cash Registers was analyzed. The planned introduction of the KSeF system was also taken into account, the degree of implementation of IT systems in Poland compared to the leading EU countries and, contrary to numerous press publications, the thesis was made that, as of October 1, 2020, no Central Invoice Register was created in Poland, because the system used from that date JPK_VAT only replaced JPK files and VAT-7 declarations, without introducing a new obligation to provide all data contained in invoices. Finally, the plans of the Ministry of Finance related to the final implementation of the Central Invoice Register in Poland were presented.

KeYwords: Central Invoice Register, Green Book, Value Added Tax, JPK, JPK-VAT.

\section{Nota o autorze}

Paweł Szymanek - dr nauk prawnych, radca prawny, doradca podatkowy; Kancelaria Prawna i Podatkowa dra Pawła Szymanka; główne obszary działalności naukowej: prawo podatkowe, ustrój i organizacja KAS; e-mail: pawelszymanek2@wp.pl; ORCID: 0000-0002-7590-7016. 